\title{
EVALUATION OF PRODUCTIVE PERFORMANCE IN TWO PLUMAGE-COLOR TYPES OF JAPANESE QUAIL USING MICROSATELLITE MARKERS.
}

\author{
Tarik S.K.M. Rabie \\ Dep. of Anim. Prod., Fac. of Agric., Suez Canal Univ. Ismailia, 41522. Egypt. \\ Corresponding author: Tarik S.K.M. Rabie E-mail: Tarik.rabie@ agr.suez.edu.eg \\ Received: 02/06/2019 \\ Accepted: 30/06/2019
}

\begin{abstract}
Two plumage-color types of Japanese quail were used to compare the meat production potentialities using five selective microsatellite markers. A total number of birds was 189 for the two plumage-colors of quail [(Brown 114; 49 males, and 65 females), and (Golden $75 ; 42$ males, and 33 females)], were used. Phenotypic data were live body weight at day $1\left(\mathrm{BW}_{0}\right)$ and measured weekly till the end of six' weeks of age $\left(\mathrm{BW}_{6}\right)$. The weight gain was calculated for intervals. The analysis of variance for live body weight at different age's data revealed that there was a highly significant difference on $\mathrm{BW}$ between plumage-color types $(\mathrm{Br}$, and $\mathrm{Gd})$ at the day1 of age $(P \geq 0.001)$. At the $6^{\text {th }}$ week of age $\left(B_{6}\right)$, there was an interaction effect between the plumage-color type and sex where the females of the $\mathrm{Br}$ were highest weight (226.92 \pm 3.75$)$ compared to others $(\mathrm{P} \geq 0.05)$. Considering the weight gain trait, the results revealed that the plumage-color type had significant effect $(\mathrm{P} \geq 0.05)$ on weight gain at the early age (from day1 to the end of the $1^{\text {st }}$ week, $\left.\mathrm{WG}_{0-1}\right)$, and $\mathrm{WG}_{1-2}$.

On molecular technique basis, a total of twenty alleles were discovered across the two types of quails. The average of alleles per locus over loci and plumage-color types was $3.30 \pm 0.15$ alleles. Only one private allele at $170 \mathrm{bp}$ with allele frequency 0.06 was present in $\mathrm{Br}$ for the locus GUJ0029. The polymorphic information content $(P I C)$ average is 0.46 with the values ranging from 0.34 at locus GUJ0063 to 0.61 at locus GUJ0023. In addition, the inter-population genetic differentiation coefficient $\left(G_{S T}\right)$ ranged from 0.0 of locus GUJ0077 to 0.077 of locus GUJ0029, and the inter-population genetic variation accounted for $3.6 \%$ of the total genetic variation. The variance among, and within individuals was observed as $93 \%$ and $7 \%$ of respectively by using AMOVA. Moreover, the Hardy-Weinberg equilibrium among the five loci was assessed. In spite of the fact that GUJ0077 locus was an exceptionally significant $(\mathrm{P} \geq 0.001)$ for $\mathrm{Gd}$, it was not for Br. In like manner, the GUJ0059 locus was significant $(\mathrm{P} \geq 0.05)$ in Gd yet not in Br. Nevertheless, the general linear model analysis showed significant association in Gd between the locus GUJ0063 not only with live body weight at $\mathrm{BW}_{0}(\mathrm{P} \geq 0.05)$, but with gain weight at $\mathrm{W}_{2}$, and $\mathrm{W}_{4}$ also $(\mathrm{P} \geq 0.05)$. Whereas, in $\mathrm{Br}$ type, the locus GUJ0029 was associated with $\mathrm{BW}_{5}(\mathrm{P} \geq 0.01)$ and $\mathrm{BW}_{6}(\mathrm{P} \geq 0.05)$. In addition, the same locus associated with weight gain at $\mathrm{W} 1(\mathrm{P} \geq 0.05)$, and $\mathrm{W} 2$ $(\mathrm{P} \geq 0.01)$. Which exposed that both of GUJ0029, and GUJ0063 loci linked with the gene(s) that responsible regulator for quails' live body weight. In conclusion, these findings of this study confirm that the association between plumage-color and productive traits have prevailed and sanctioned by using the molecular markers.
\end{abstract}

Keywords: Microsatellite marker-body weight-Plumage-color-association-Quail. 
Tarik S.K.M. Rabie

\section{INTRODUCTION}

Japanese quail is recommended for genetic studies due to its early sexual maturity, short generation interval, low feed consumption and therefore the economy of production ensuing from quicker rate of growth and its smaller body size (Devi et al., 2010, Jatoi et al., 2013). Live body weight is a standout among the most noteworthy traits since its general straightforwardness of estimation as well as for its relationship with other profitable meat production traits. Furthermore, it is known to be decently to exceptionally heritable trait in this manner the choice of heavier individuals should result in the genetic improvement of the trait (Oke et al., 2004). Researchers have reported the heritability of body weight in Japanese quail to be between 0.30 and 0.72 at different ages. Caron et al. (1990) clarified the significance, with regards to selection programs of hereditary parameters gauges for creation traits of Japanese quail.

Genetic diversity is considered from the polymorphism of morphology, chromosome, blood protein and DNA. The mutation diversity of quail is additionally a potential biomedical asset and can be utilized to clarify the pigmentation, morphology and metabolic regulatory mechanisms (Pang, 2009). Twenty-seven plumage colors have been reported (Cheng \& Kimura 1990), therefore, Mizutani, (2003) reported that more than 50 plumage-color-mutations can be isolated from the wild-type of Japanese quail. Moreover, many plumage color variants of Japanese quails were studied ( $\mathrm{Yu}$ et.al., 2009; Bai et al., 2016a). The purposes behind choosing a particular plumage color in meat-type strains of quail may be expected to satisfy the plumage design as explicit genetic advantages for higher meat yield. Yu et.al. (2009) reported that color mutation is the result of incompletely recessive mutations of autosome. Information about growth performance and plumage color mutations is insufficient to assess their use in commercial production. Corresponded impacts of Japanese quail plumage color hereditary variations on performance traits have just been concentrated for a couple of transformations, for example, the roux mutation, which can be utilized for autosexing at $1 \mathrm{~d}$ of age (Minvielle et al., 1999); the curly mutation, which is related to expanded live body weight (Minvielle et al., 2005); the Dominant Lethal Yellow mutation (Minvielle et al., 2007); the recessive white gene (Petek et al., 2004); Yellowish plumage is procured in a solitary autosomal passive gene (Ishishita et al. 2018). a recessive sex-linked red plumage mutation, which might indeed belong to the brown locus (Liu and Liu, 1991); genetic analysis of brown plumage color in quail (Yilmaz and Çaglayan, 2008); and genes determining yellow and dotted white plumage patterns in Japanese quail (Yildiz and Kesici, 1997). In addition, Bai et al. (2016a) selected nine microsatellite markers to detect the polymorphism of quails of four colors. The relationship between plumage color and the productive and reproductive traits in Japanese quail have been affirmed (Thornberry, 2016). Recently, hundred microsatellite markers were made for Japanese quail (Kayang et al. 2000, 2002) which used to fabricate a linkage map (Kayang et al. 2004). The universality of SSR can provide the absolute marker for gene function and completely mirror the comparability level of the genomic useful territory. Its polymorphism can even more likely clarify the phenotypic contrasts. gotten from conventional genomes is extremely poor between the species 
Microsatellite marker-body weight-Plumage-color-association-Quail.

(Bed'hom et al. 2012). Subsequently, researching of the relationship between plumage color and bird's performance obviously has criticalness in the program of creating meat or egg type strains with a specific plumage-structure in the Japanese quail (Minvielle et al., 2007). The present examination was embraced to compare the meat production possibilities of two plumage-color of Japanese quail through molecular procedures utilizing five particular microsatellite markers.

\section{MATERIALS AND METHODS Husbandry and traits}

Day-old quail chicks from different plumage-color type (Brown and Golden) were wing banded on the day of hatch and brooded in floor pens. The house temperature was kept at about $35^{\circ} \mathrm{C}$ amid the initial 3 days, $32^{\circ} \mathrm{C}$ during next 4 days and step by step diminished by $2^{\circ} \mathrm{C}$ week after week until the finish of the third kept up at $24^{\circ} \mathrm{C}$. Chicks were fed a growing diet as ad libitum contained $24.1 \%$ protein and $2860 \mathrm{kcal} / \mathrm{kg}$. A total number of birds was 189 for the two plumage-colors of quail [(Brown 114, 49 males, and 65 females), and (Golden 75, 42 males, and 33 females)], were used. The traits were live body weight at day one $\left(\mathrm{W}_{0}\right)$ and measured weekly till the six' weeks of age $\left(\mathrm{W}_{6}\right)$. The weight gain was calculated $\left(\mathrm{WG}=\mathrm{W}_{2}-\right.$ $\mathrm{W}_{1}$ ).

\section{Collecting blood samples and DNA extraction}

A total of 50 individual blood samples representing 25 sample from each plumage-color type, were randomly collected from females. About $0.15 \mathrm{ml}$ of blood from wing vein was individually collected in a tube treated with K3-EDTA (FL medical, Italy) and stored at $20^{\circ} \mathrm{C}$ until DNA extraction. Genomic DNA was extracted using PureLink Genomic DNA Mini; Microcentrifuge spin-column format (Invitrogen ${ }^{\mathrm{TM}} \mathrm{K} 182001$, USA) has used to provide a superior performance and high purity and yield of extracted DNA. The quality of extracted DNA was examined by NanoDrop® ND-1000 UVVis Spectrophotometer enabling highly accurate analyses with remarkable reproducibility.

\section{Selection of markers and genotyping}

Five microsatellite markers were selected (Table 1) according to Kayang et al. (2002). To facilitate, all markers obtained were first tested on the quail's genomic DNA for polymorphism, then the PCR reactions were performed in a final volume of $50 \mu \mathrm{l}$ reaction mixture composed of $3 \mu 1 \mathrm{DNA}(40 \mathrm{ng} / \mu \mathrm{l}), 45 \mu \mathrm{l}$ of PCR SuperMix 1.1x concentration (Invetrogen, USA), $1.5 \mu$ l of each primer $(10 \mathrm{pmol} / \mu \mathrm{l})$. The amplification conditions on a Genemate B960 gradient thermal cycling platform were as follows: initial denaturation step at $94^{\circ} \mathrm{C}$ for $3 \mathrm{~min}, 30$ cycles of amplification $(45 \mathrm{~s}$ of denaturation at $94^{\circ} \mathrm{C}, 60 \mathrm{~s}$ of annealing at $55^{\circ} \mathrm{C}, 56^{\circ} \mathrm{C}$ or $60^{\circ} \mathrm{C}$ based on the optimal annealing temperature for the used primer, 60 s of extension at $72^{\circ} \mathrm{C}$ ), and followed by final extension at $72^{\circ} \mathrm{C}$ for $12 \mathrm{~min}$. PCR products were electrophoresed on $1.5 \%$ agarose gel containing $0.5 \%$ ethidium bromide which viewed under UV light, and documented using Uvp-BioDoc system. Therefore, genotyping of the microsatellite markers were analyzed in the automatic multi-capillary electrophoresis QIAxcel system using the QIAxcel DNA Screening Kit. Polymorphism information content (PIC) was calculated according to the formula:

$$
\text { PIC }=1-\sum_{i=1}^{n} P_{i}^{2}-\sum_{i=1}^{n-1} \sum_{j=i+1}^{n} 2 P_{i}^{2} P_{j}^{2}
$$

where $P_{i}$ and $P_{j}$ are the frequencies of the $i^{\text {th }}$ and $j^{\text {th }}$ alleles at a locus with $l$ alleles in 


\section{Tarik S.K.M. Rabie}

a population, respectively and $n$ was the number of alleles (Bostein et al., 1980) by using CERVUS version 3 software (Kalinowski et al., 2007). In addition, genetic differentiation coefficient $\left(G_{S T}\right)$ was calculated according to the formula $G_{S T}=1-\mathrm{H}_{\mathrm{s}} / \mathrm{H}_{\mathrm{t}}$, where $\mathrm{H}_{\mathrm{s}}$ is average heterozygosity of different quail populations, $\mathrm{H}_{\mathrm{t}}$ is total population average heterozygosity.

\section{Statistical analysis}

Phenotypic analysis

Live body weight and weight gain traits for all intervals were evaluated with the general linear model implemented by the $\mathrm{R}$ packages as the following equation

$Y_{i j k}=\mu+P_{i}+S_{j}+(P S)_{i j}+\varepsilon_{i j k}$

where $\mu$ is the overall mean, $P_{i}$ is the effect of $\mathrm{i}^{\text {th }}$ plumage-color type, $S_{j}$ is the effect of $\mathrm{j}^{\text {th }}$ Sex, $P S_{i j}$ is the effect of interaction between $P_{i}$ and $S_{j}$ and $\varepsilon_{i j k}$ is the random error. least squares means, and standard errors of body weight was estimated by using "emmeans" package in $\mathrm{R}$ according to Lenth (2016), and a cld (compact letter display) method that lists the LS means along with grouping symbols for pairwise contrasts, and $\mathrm{P}$ value adjustment with "tukey" method for comparing the breeds of body weight estimates was used by "multcompView" package (Graves et al. 2015) which are available from the comprehensive $\mathrm{R}$ archive network (https://cran.r-project.org/)

\section{Association between the plumage color} mutation and live body weight

From the data observed from codominant markers, genetic diversity was assessed by calculating the observed $(\mathrm{No})$ and effective $(\mathrm{Ne})$ number of alleles, the observed $(\mathrm{Ho})$ and the expected $(\mathrm{He})$ heterozygosity using the GenAlEx 6.5 program (Peakall and Smouse, 2012). Polymorphism information content (PIC) was assessed using the program Cervus
3.0.7 (Kalinowski et al., 2007). "The Fstatistics of pairwise genetic differentiation among the populations $\left(F_{S T}\right)$, reduction in heterozygosity due to inbreeding for each locus $\left(F_{I T}\right)$ and the reduction in heterozygosity due to inbreeding within each population $\left(F_{I S}\right)$ were calculated". Additionally, deviation from HWE at each locus in each plumagecolor type was tested using GenAlEx 6.5. To minimize the consequences of genotyping errors, those alleles found in only one type in at least two individuals were considered to be private ones. Chisquare test was performed to identify the existence of significant differences between plumage-color types with regard to genotypic frequencies and significant associations between the allelic segregation of the markers. Consequently, the association between microsatellite markers and BW trait at interval weeks was evaluated with the generalized linear model by $R$ as follows: $Y_{i j k}=\mu+G_{i}+P_{j}+e_{i j k}$ where $Y_{i j k}$ is the observed value of the $i j k^{\text {th }}$ trait; $\mu$ is the mean value of the trait; $G_{i}$ is the effect of the $i^{\text {th }}$ genotype; $\mathrm{P}_{\mathrm{j}}$ is the effect of the $\mathrm{j}^{\text {th }}$ plumage-color type; and $\mathrm{e}_{\mathrm{ijk}}$ is the random error effect $(\mathrm{P} \geq 0.05)$. The statistical model was based on that described by Ma et al. (2014) with amendment. Followed by multivariate analysis of variance analysis which was performed using "mvtnorm" package in R for the association between detected alleles and phenotype observations.

\section{RESULTS AND DISCUSSION}

\section{Live Body weight and weight gain}

The analysis of variance for live body weight (BW) at different age's data revealed that there was a highly significant difference on live body weight between plumage-color types $(\mathrm{Br}$, and $\mathrm{Gd})$ at the dayl of age $(\mathrm{P} \geq 0.001)$. where the least square means were $8.63 \pm 0.09$, and $9.43 \pm$ 
Microsatellite marker-body weight-Plumage-color-association-Quail.

0.12 for $\mathrm{Br}$ and $\mathrm{Gd}$ color, respectively. The same trend was at $\mathrm{BW}_{1}$, and $\mathrm{BW}_{2}$, where significant differences $(\mathrm{P} \geq 0.01)$ were found between them for both $\mathrm{BW}_{1}(31.70 \pm$ $0.64,34.5 \pm 0.79)$ and $\mathrm{BW}_{2}(72.70 \pm 1.29$, $78.80 \pm 1.58$ ) for $\mathrm{Br}$ and $\mathrm{Gd}$ color, respectively (Table 2). Likewise, Inci et al. (2015) found significant differences between dark brown and golden color groups $(55.8 \pm 1.5,60.6 \pm 1.4$, respectively). At the $6^{\text {th }}$ week of age $\left(\mathrm{BW}_{6}\right)$, there was an interaction effect between the plumagecolor type and sex where the females of the $\mathrm{Br}$ were highest weight (226.92 \pm 3.75$)$ compared to others $(\mathrm{P} \geq 0.05)$. These findings were dissimilar with Nasr et al. (2017) where the lowest body weight (174.68 g) was obtained for brown when they compared between four types of plumage-colors (white, golden, gray and brown). In addition, Inci et al. (2015) found different direction where the females of both dark brown and golden was highest than males $(\mathrm{P} \geq 0.05)$. Interestingly, the live body weight of $\mathrm{Br}$ type at $\mathrm{BW}_{5}$ was heavier $(195.0 \pm 1.99)$ than those obtained in different study

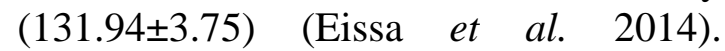
Moreover, Mahmoud et al. (2014) found that the brown genotype had significantly heavier BW at the ages 21, 28, 35 day compared with white plumage-color.

Considering the weight gain trait, the results revealed that the plumage-color type had significant effect $(\mathrm{P} \geq 0.05)$ on weight gain at the early age (from day1 to the end of the $1^{\text {st }}$ week, $\left.\mathrm{WG}_{0-1}\right)$, and $\mathrm{WG}_{1-2}$ (Table 2). In addition, there was no significant differences at remained interims. Nevertheless, the generalized linear model analysis showed significant association in $\mathrm{Gd}$ between the locus GUJ0063 not only with live body weight at $\mathrm{BW}_{0}(\mathrm{P} \geq 0.05)$, but with gain weight at $\mathrm{W}_{2}$, and $\mathrm{W}_{4}$ also $(\mathrm{P} \geq 0.05)$. Whereas, in $\mathrm{Br}$ type, the locus GUJ0029 was associated with $\mathrm{BW}_{5}(\mathrm{P} \geq 0.01)$ and $\mathrm{BW}_{6}(\mathrm{P} \geq 0.05)$. In addition, the same locus associated with weight gain at $\mathrm{W}_{1}(\mathrm{P} \geq 0.05)$, and $\mathrm{W}_{2}(\mathrm{P} \geq$ 0.01). Which exposed that both of GUJ0029, and GUJ0063 loci linked with the gene(s) that responsible regulator for quails' live body weight. These findings corresponding to Thornberry (2016), who report the association between plumagecolor and productive and reproductive traits in Japanese quail have existed.

\section{Locus profile polymorphism}

The results of microsatellite marker's polymorphism, and the allele frequencies of the five microsatellite markers in the two plumage-color types $(\mathrm{Br}$, and $\mathrm{Gd})$ are presented in Figure 1. A total of twenty alleles were discovered across the two types of quails. the typical range of alleles per locus discovered over loci and plumage-color types was $3.30 \quad \pm 0.15$ alleles. The highest observed number was 4 alleles and was detected in markers GUJ0023 and GUJ0029, whereas, the microsatellite markers GUJ0023 has a relatively rich polymorphism, with four alleles detected for $\mathrm{Br}$, and $\mathrm{Gd}$ quails. In addition, the lowest number was 3 alleles (Table 3). These results were relatively coordinated with Bai et al. (2013) found that the average number of alleles was 5.3 and varied from 3 for GUJ0063 to 7 alleles for GUJ0057 with Chinese yellow quails. Furthermore, Kayang et al. (2002) found that the average number of alleles for Japanese quail was 3.7 alleles per locus when a hundred microsatellite markers have been utilized. All locus utilized in this investigation were polymorphic (Figure 1), and this is because of the distinctions in dissemination of the allele frequency for each allele estimate among the quails' plumage-color types. The highest allele frequency was 0.78 at locus 
GUJ0063 with allele size of $240 \mathrm{bp}$. Moreover, only a private allele at $170 \mathrm{bp}$ with allele frequency 0.06 was present in $\mathrm{Br}$ for the locus GUJ0029 (Figure 1). The effective number of alleles $(\mathrm{Ne})$ of all microsatellite markers over the two plumage-color types in quail went from 1.61 to 2.80 . Although, these values were lower than the average of $\mathrm{Ne}$ for other study was which ranged from 1.8574 to 5.8754 (Bai et al. 2016b), and it was in harmonized with Bai et al. (2016a) who found the Ne ranged from 1.27 to 4.79.

\section{The heterozygosis across plumage- color types.}

The observed $(\mathrm{Ho})$ and expected $(\mathrm{He})$ heterozygosity (Table 3), and the polymorphic information content (PIC) for each marker across the plumage-color types are conferred in Table 4. He or the gene diversity are considered as the most extensively parameters used to magnitude the genetic diversity across and within the populations (Nei 1973). The mean of $\mathrm{He}$ values were almost equal $(0.50 \pm 0.08$, $0.50 \pm 0.05)$ for $\mathrm{Br}$, and $\mathrm{Gd}$ respectively (Table 3).

Remarkably, marker GUJ0029 has lowest values for both $\mathrm{He}$ and $\mathrm{Ho}$ (0.22 and 0.24), while the highest values $(0.71$, and 0.88 for $\mathrm{He}$ and $\mathrm{Ho}$ ) achieved by locus GUJ0023. These results are expected because the heterozygosity values realized with microsatellite markers were generally averaged between 0.3 to 0.8 . Meng et al. (2007) found that the average heterozygosity was 0.71 of 12 microsatellite markers in North Korean quails. In current study, the $\mathrm{Ho}$ for all loci averaged $0.495 \pm 0.06$ While, the overall mean of $\mathrm{He}$ was $0.50 \pm 0.05$. Furthermore, many researchers studied the average heterozygosity of different numbers of loci in many quail species, and obtained a value ranged from 0.13 to 0.85
(Kayang et al. 2002; Farrag et al. 2011; Hossein et al. 2011; Bai et al. 2016b). The observable outcomes may be because of the number of markers or potentially the quantity of tests within breeds that utilized. The polymorphic information content (PIC) may be utilized to discover the heterozygosity and the alleles' numeral in the populace. The PIC average is 0.46 with the values ranging from 0.34 at locus GUJ0063 to 0.61 at locus GUJ0023 (Table 4). Harmoniously, Kayang et al. (2002) found that the average PIC was 0.48 with the range from 0.0 to 0.73 . These results contradictory with the results of Bai et al. (2013) who found the highest PIC was 0.81 of GUJ0077 and the lowest PIC value was 0.51 of GUJ0063. Where the results of this study revealed the PIC values for GUJ0077 and GUJ0077 was 0.34 , and 0.49 respectively (Table 4 ). In addition, although two microsatellite markers (GUJ0059, and GUJ0063) have used in different study (Farrag et al. 2011), contemporary information demonstrated a similar pattern however not the values. The reason behind that may because of the diverse quail breeds or types. Therefore, from the PIC data, the microsatellite markers that used are reasonably informative and would be useful for genetic polymorphism studies and comparative mapping then breeding programs in quails.

\section{Genetic differentiation coefficient and Hardy-Weinberg equilibrium}

The inter-population genetic differentiation coefficient $\left(G_{S T}\right)$ ranged from 0.0 of locus GUJ0077 to 0.077 of locus GUJ0029, and the over mean for all studied loci was 0.036 which means that inter-population genetic variation accounted for $3.6 \%$ of the total genetic variation (Table 4). Therefore, the differentiation degree among the two 
Microsatellite marker-body weight-Plumage-color-association-Quail.

plumage-color types quail was small. Accordingly, Bai et al. (2016a) reported the inter-population genetic differentiation coefficient was $5.19 \%$. In addition, Bai et al. (2016b) observed the $G_{S T}$ ranged from 0.0103 to 0.0773 when they worked on three populations of quail. Furthermore, Chang et al. (2007) found $G_{S T}$ of 3 quail populations was 0.0109-0.055. Consequently, it can be accentuated as, the low differentiation has achieved, and the high homology existed among them.

The Hardy-Weinberg equilibrium among the five loci was estimated. Although GUJ0077 locus was a highly significant $(\mathrm{P} \geq 0.001)$ for $\mathrm{Gd}$, it was not significant for Br. Likewise, the GUJ0059 locus was significant $(\mathrm{P} \geq 0.05)$ in $\mathrm{Gd}$ but not in $\mathrm{Br}$ (Table 3). These findings approved by Bai et al. (2016b) who realized that only GUJ0077 in yellow population, and GUJ0023, GUJ0029 in white population meet Hardy-Weinberg law ( $\mathrm{P} \geq 0.05)$.

\section{Genetic Variation and breeds diversity}

To measure the extent of molecular variety, locus-by-locus investigation of molecular variance (AMOVA), $F$ were gotten utilizing AMOVA approach. Besides, the F $_{\text {ST }}$ esteem estimates the level of hereditary differentiation. The analysis of molecular variance revealed that $93 \%$ and $7 \%$ of variance was observed among, and within individuals respectively. Likewise, Chang et al. (2007) reported that the genetic variance between populations accounted for $1.09 \%-5.48 \%$ of the total genetic variance, which showed that the fluctuation was principally delivered from within populations. These results disputed to the findings of Farrag et al. (2011), who found the values were approximately $85 \%$, within individuals and 3.61 among quails' populations. Two main parameters were evaluated in this study to estimate the genetic variation of the two-plumagecolor types of quail, genetic differentiation $\left(F_{S T}\right)$, and genetic distance. The values of $F_{S T}$ of five locus a cross plumage-color types of quails are shown in Table 4. The $F_{S T}$ comparisons from entirely unexpected components of the genome will offer bits of knowledge into the statistic history of populations (Holsinger and Weir, 2009).

The obtained $F_{S T}$ ranged from 0.01 to 0.09 , in this manner, it considered as slight hereditary contrasts as indicated by microsatellite markers that utilized (Balloux and Lugon-Moulin, 2002). The obtained $F_{S T}$ esteem as lower than 0.05 just in locus GUJ0063 may reflect generous genetic differentiation. A previous report prompt that microsatellite markers employed in studies of genetic variation and distance ought to don't have any fewer than four alleles so as to cut back the standard errors of distance estimates (Barker, 1994), and that such microsatellite markers ought to have a $\mathrm{Ho}$ of between 0.3 and 0.8 within the populations (Takezaki and Nei, 1996). In conclusion, the findings of this study confirm that the association between plumage-color and productive traits have prevailed and sanctioned by using the molecular markers. Therefore, microsatellite markers were indicated to be expedient of genetic variation studies. 
Table (1): Molecular characteristics, information and annealing temperature for five microsatellite loci.

\begin{tabular}{|c|c|c|c|}
\hline Locus name & Chromosome No. & GenBank accession number & $\left(^{\mathbf{0}}\right)^{\mathbf{1}}$ \\
\hline GUJ0023 & 14 & AB035833 & 55 \\
GUJ0029 & 6 & AB035839 & 55 \\
GUJ0059 & 5 & AB063127 & 60 \\
GUJ0063 & 2 & AB063131 & 55 \\
GUJ0077 & 1 & AB063145 & 56 \\
\hline
\end{tabular}

Table (2): The differences in live body weight (BW) among quails with different plumage color. The least square means for live body weight of quails with different sex and plumage color. $1=$ annealing temperature.

\begin{tabular}{|c|c|c|c|c|c|c|c|c|}
\hline \multirow{3}{*}{ Traits } & \multicolumn{2}{|c|}{ Genotype effect } & \multicolumn{2}{|c|}{ Sex effect } & \multicolumn{4}{|c|}{ Genotype by sex interaction effect } \\
\hline & \multirow{2}{*}{ Brown } & \multirow{2}{*}{ Golden } & \multirow{2}{*}{ Males } & \multirow{2}{*}{ Females } & \multicolumn{2}{|c|}{ Brown } & \multicolumn{2}{|c|}{ Golden } \\
\hline & & & & & Males & Females & Males & Females \\
\hline $\mathrm{BW}_{0}$ & $8.63 \pm 0.09$ & $9.43 \pm 012$ & $9.06 \pm 0.11$ & $9.00 \pm 0.11$ & $8.61 \pm 014^{\mathrm{a}}$ & $8.65 \pm 0.12^{\mathrm{a}}$ & $9.52 \pm 0.16^{\mathrm{b}}$ & $9.34 \pm 0.19^{\mathrm{b}}$ \\
\hline $\mathrm{BW}_{1}$ & $31.70 \pm 0.64^{\mathrm{a}}$ & $34.50 \pm 0.79^{b}$ & $32.60 \pm 0.71$ & $33.6 \pm 0.72$ & $30.34 \pm 0.85^{\mathrm{a}}$ & $33.04 \pm 1.01^{\mathrm{ab}}$ & $34.83 \pm 0.95^{\mathrm{b}}$ & $34.10 \pm 0.93^{\mathrm{ab}}$ \\
\hline $\mathrm{BW}_{2}$ & $72.70 \pm 1.29^{\mathrm{a}}$ & $78.80 \pm 1.58^{\mathrm{b}}$ & $75.00 \pm 1.43$ & $76.40 \pm 1.45$ & $70.58 \pm 1.74^{\mathrm{a}}$ & $74.72 \pm 1.82^{\mathrm{ab}}$ & $79.46 \pm 2.20^{\mathrm{b}}$ & $78.15 \pm 2.04^{\mathrm{ab}}$ \\
\hline $\mathrm{BW}_{3}$ & $117.00 \pm 1.68$ & $122.00 \pm 2.06$ & $118.00 \pm 1.86$ & $121.00 \pm 1.89$ & $113.5 \pm 2.47$ & $120.55 \pm 2.10$ & $121.65 \pm 3.30$ & $122.24 \pm 2.48$ \\
\hline $\mathrm{BW}_{4}$ & $163.00 \pm 1.74$ & $165.00 \pm 2.14$ & $163.00 \pm 1.93$ & $166.00 \pm 1.96$ & $160.12 \pm 2.40$ & $166.52 \pm 2.45$ & $165.11 \pm 3.01$ & $164.62 \pm 2.8$ \\
\hline $\mathrm{BW}_{5}$ & $195.00 \pm 1.99$ & $200.00 \pm 2.44$ & $195.00 \pm 2.21$ & $200.00 \pm 2.24$ & $189.38 \pm 2.53^{\mathrm{a}}$ & $200.39 \pm 2.87^{\mathrm{b}}$ & $200.85 \pm 3.53^{b}$ & $199.65 \pm 3.22^{\mathrm{ab}}$ \\
\hline $\mathrm{BW}_{6}$ & $218.00 \pm 2.59$ & $218.00 \pm 3.18$ & $214.00 \pm 2.88^{\mathrm{b}}$ & $222.00 \pm 2.92^{\mathrm{a}}$ & $208.82 \pm 3.26^{\mathrm{a}}$ & $226.92 \pm 3.75^{b}$ & $218.93 \pm 4.83^{\mathrm{ab}}$ & $218.03 \pm 3.73^{\mathrm{ab}}$ \\
\hline $\mathrm{WG}_{0-1}$ & $23.1 \pm 0.62^{\mathrm{a}}$ & $25.0 \pm 0.76 \mathrm{~b}$ & $23.5 \pm 0.69$ & $24.6 \pm 0.70$ & $21.70 \pm 0.93^{\mathrm{a}}$ & $24.40 \pm 0.81^{\mathrm{ab}}$ & $25.30 \pm 1.00^{\mathrm{b}}$ & $24.80 \pm 1.10^{\mathrm{ab}}$ \\
\hline $\mathrm{WG}_{1-2}$ & $41.0 \pm 0.87^{\mathrm{a}}$ & $44.3 \pm 1.07 \mathrm{~b}$ & $42.4 \pm 0.97$ & $42.9 \pm 0.98$ & $40.20 \pm 1.31^{\mathrm{a}}$ & $41.7 \pm 1.14^{\mathrm{a}}$ & $44.6 \pm 1.42^{\mathrm{b}}$ & $44.10 \pm 1.60^{\mathrm{b}}$ \\
\hline $\mathrm{WG}_{2-3}$ & $43.5 \pm 1.05$ & $43.1 \pm 1.30$ & $42.6 \pm 1.17$ & $44.1 \pm 1.19$ & $42.90 \pm 1.59$ & $44.00 \pm 1.38$ & $42.2 \pm 1.72$ & $44.10 \pm 1.94$ \\
\hline $\mathrm{WG}_{3-4}$ & $43.6 \pm 2.20$ & $41.0 \pm 2.70$ & $41.5 \pm 2.44$ & $43.1 \pm 2.48$ & $43.30 \pm 3.32$ & $43.90 \pm 2.88$ & $39.7 \pm 3.58$ & $42.40 \pm 4.04$ \\
\hline $\mathrm{WG}_{4-5}$ & $31.1 \pm 1.43$ & $35.5 \pm 1.76$ & $32.2 \pm 1.59$ & $34.4 \pm 1.62$ & $28.80 \pm 2.16$ & $33.4 \pm 1.88$ & $35.60 \pm 2.34$ & $35.40 \pm 2.64$ \\
\hline $\mathrm{WG}_{5-6}$ & $22.7 \pm 1.89$ & $18.3 \pm 2.32$ & $18.7 \pm 2.10$ & $22.4 \pm 2.13$ & $19.40 \pm 2.85$ & $26.1 \pm 2.48$ & $18.00 \pm 3.08$ & $18.70 \pm 3.48$ \\
\hline
\end{tabular}

$\mathrm{a}, \mathrm{b}, \mathrm{c}$ : The differences among the values bearing different superscript on the same row line are significant $(\mathrm{P} \leq 0.05)$. 
Table (3): The observed (Ho) and expected (He) heterozygosity and Hardy-Weinberg equilibrium (HWE) for the two studied' plumage-color types.

\begin{tabular}{|c|c|c|c|c|c|c|c|c|c|}
\hline \multirow{2}{*}{$\begin{array}{l}\text { Plumage- } \\
\text { color }\end{array}$} & \multirow{2}{*}{ Locus } & \multirow{2}{*}{$\mathbf{N}$} & \multirow{2}{*}{$N a$} & \multirow{2}{*}{$\mathrm{Ne}$} & \multirow{2}{*}{ Ho } & \multirow{2}{*}{ He } & \multirow{2}{*}{$\mathbf{F}$} & \multicolumn{2}{|c|}{ Hardy-Weinberg } \\
\hline & & & & & & & & P-value & HWE \\
\hline \multirow[t]{6}{*}{ Brown } & GUJ0023 & 25 & 4.00 & 3.44 & 0.88 & 0.71 & -0.24 & 0.574 & ns \\
\hline & GUJ0029 & 25 & 4.00 & 1.28 & 0.24 & 0.22 & -0.09 & 0.998 & ns \\
\hline & GUJ0059 & 24 & 3.00 & 1.88 & 0.58 & 0.47 & -0.25 & 0.493 & ns \\
\hline & GUJ0063 & 23 & 3.00 & 2.07 & 0.65 & 0.52 & -0.26 & 0.427 & ns \\
\hline & GUJ0077 & 24 & 3.00 & 2.33 & 0.46 & 0.57 & 0.20 & 0.128 & ns \\
\hline & Mean \pm SE & $24.2 \pm 0.37$ & $3.40 \pm 0.2$ & $2.20 \pm$ & $0.56 \pm 0.11$ & $0.50 \pm$ & $-0.13 \pm 0.09$ & & \\
\hline \multirow[t]{6}{*}{ Golden } & GUJ0023 & 23 & 4.00 & 2.16 & 0.61 & 0.54 & -0.14 & 0.233 & ns \\
\hline & GUJ0029 & 24 & 3.00 & 1.94 & 0.50 & 0.48 & -0.03 & 0.942 & ns \\
\hline & GUJ0059 & 24 & 3.00 & 2.70 & 0.50 & 0.63 & 0.21 & 0.034 & $*$ \\
\hline & GUJ0063 & 25 & 3.00 & 1.54 & 0.28 & 0.35 & 0.20 & 0.357 & ns \\
\hline & GUJ0077 & 24 & 3.00 & 2.08 & 0.25 & 0.52 & 0.52 & 0.004 & $* *$ \\
\hline & Mean \pm SE & $24.0 \pm 0.32$ & $3.20 \pm 0.2$ & $2.08 \pm 0.19$ & $0.43 \pm 0.07$ & $0.50 \pm$ & $0.15 \pm 0.11$ & & \\
\hline \multicolumn{2}{|c|}{ Overall Mean \pm SE } & $24.1 \pm 0.23$ & $3.30 \pm 0.1$ & $2.142 \pm 0.1$ & $0.495 \pm 0.06$ & 0.500 & $0.011 \pm 0.08$ & & \\
\hline
\end{tabular}

$\mathrm{Na}=$ No. of different Alleles, $\mathrm{Ne}=$ No. of effective Alleles, $\mathrm{Ho}=$ Observed heterozygosity, $\mathrm{He}=$ Expected heterozygosity,

$\mathrm{F}=$ Fixation Index $=(\mathrm{He}-\mathrm{Ho}) / \mathrm{He}$ 
Table (4): Characterization of the microsatellite markers used in this study.

\begin{tabular}{|c|c|c|c|c|c|c|c|c|c|c|c|}
\hline $\begin{array}{c}\text { Microsatellite marker } \\
\text { (Locus) }\end{array}$ & Mean N & $\begin{array}{c}\text { Mean } \\
\boldsymbol{N a}\end{array}$ & $\begin{array}{l}\text { Mean } \\
\boldsymbol{N e}\end{array}$ & $\begin{array}{l}\text { Mean } \\
\boldsymbol{H o}\end{array}$ & $\boldsymbol{H}_{\boldsymbol{s}}$ & $\boldsymbol{H}_{\boldsymbol{t}}$ & $\boldsymbol{F}_{\boldsymbol{I S}}$ & $\boldsymbol{F}_{\boldsymbol{I T}}$ & $\boldsymbol{F}_{\boldsymbol{S T}}$ & $\boldsymbol{G}_{\boldsymbol{S T}}$ & $\boldsymbol{P I C}$ \\
\hline GUJ0023 & 48.00 & 4.00 & 2.80 & 0.74 & 0.62 & 0.65 & -0.20 & -0.14 & 0.05 & 0.04 & 0.61 \\
GUJ0029 & 49.00 & 3.50 & 1.61 & 0.37 & 0.35 & 0.39 & -0.05 & 0.04 & 0.09 & 0.07 & 0.35 \\
GUJ0059 & 48.00 & 3.00 & 2.29 & 0.54 & 0.55 & 0.58 & 0.01 & 0.07 & 0.05 & 0.04 & 0.52 \\
GUJ0063 & 48.00 & 3.00 & 1.81 & 0.47 & 0.43 & 0.45 & -0.07 & -0.03 & 0.04 & 0.02 & 0.34 \\
GUJ0077 & 48.00 & 3.00 & 2.21 & 0.35 & 0.55 & 0.55 & 0.35 & 0.36 & 0.01 & 0.00 & 0.49 \\
Overall mean & 48.200 & 3.300 & 2.142 & 0.495 & 0.500 & 0.525 & 0.010 & 0.059 & 0.046 & 0.03 & 0.46 \\
\hline
\end{tabular}

$\mathrm{Na}=$ No. of different alleles, $\mathrm{Ne}=$ No. of effective alleles, Mean $\mathrm{Ho}=$ Average $\mathrm{Ho}$ across the populations., $H_{s}=$ Mean Expected heterozygosity $H e$ over k pops. $\mathrm{H}_{\mathrm{t}}=$ Total expected heterozygosity, $\mathrm{F}_{\mathrm{IS}}=$ Inbreeding coefficient within individuals. $F_{I T}=\left(H_{t}-\mathrm{Mean} H o\right) / H_{t}$, content 


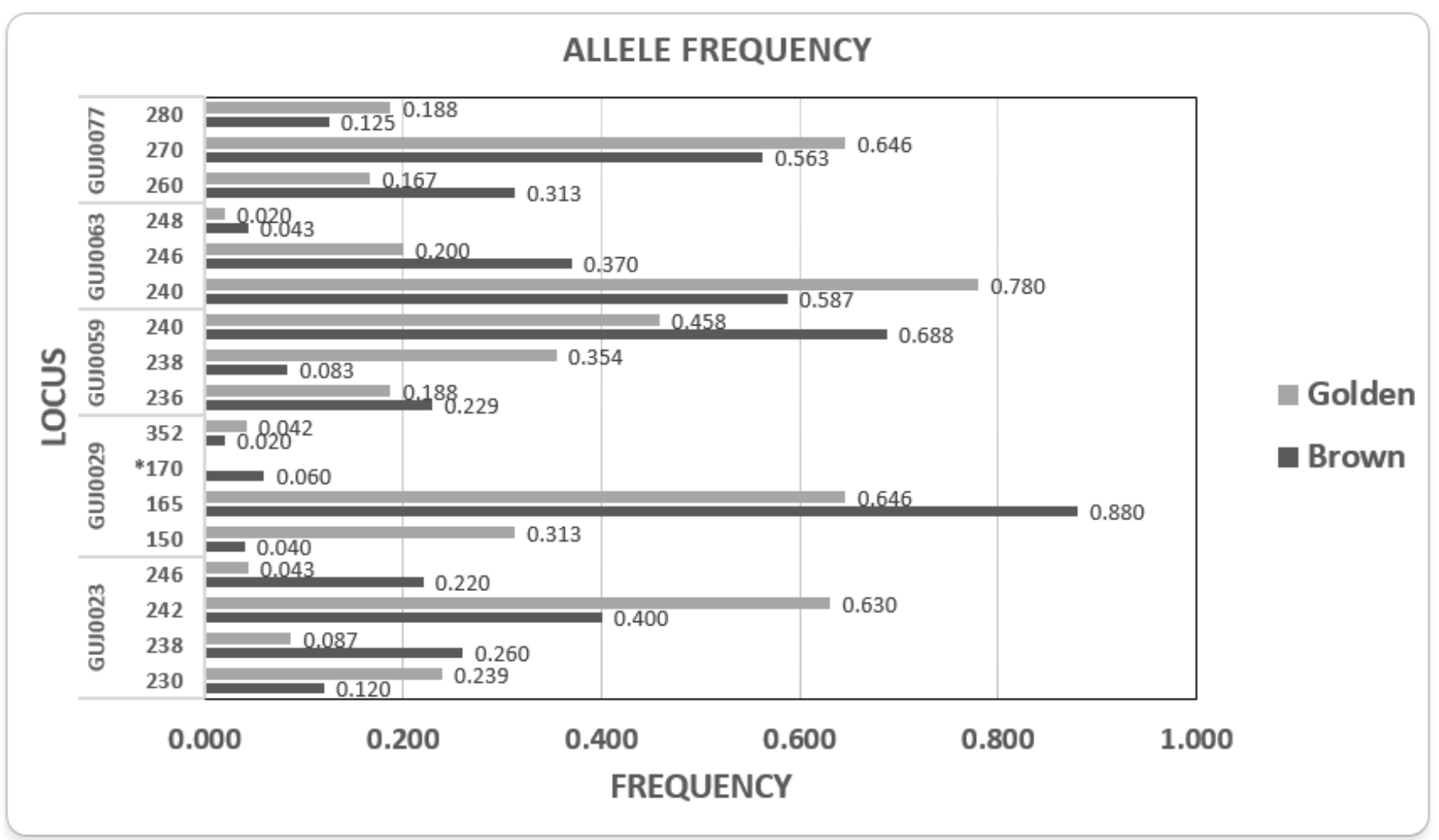

Figure (1): The observed allelic size and frequency per locus in each plumage-color type of quails. The allele size with asterisk is a private allele for each plumage-color type. 
Microsatellite marker-body weight-Plumage-color-association-Quail.

\section{REFERENCES}

Bai J. Y., Pang Y.Z., Wu S. J., Yu M.Q., Zhang X.H., Zhao S.J., Xu H.W. 2013. Polymorphism analysis of Chinese yellow quail using microsatellite markers. J. Anim. Plant Sci. 23:1072-1076.

Bai J.Y., Pang Y.Z., Qi Y.X., Zhang X.H., Yun X.Y. 2016a. Development and application of Est-Ssr markers in quails. Brazilian Journal of Poultry Science. Special Issue Quails / 27-32.

Bai J.Y., Pang Y.Z., Wu S. J., Yu M.Q., Zhang X.H. 2016b. Analysis of genetic diversity of four quails by microsatellite markers. Indian J. Anim. Res., 50: 1-7

Balloux, F., Lugon-Moulin, N. 2002. The estimation of population differentiation with microsatellite markers. Mol. Ecol. 11:155-165.

Barker J.S.F. 1994. A global protocol for determining genetic distance among domestic livestock breeds. Proceedings of the 5th World Congress on Genetics Applied to Livestock Production, (GALP'94), Guelph, Ontario, Canada, pp: 501-508.

Bed'hom B., Vaez M., Coville J-L., Gourichon D., Chastel O., Follett S., Burke T., Minvielle F. 2012. The lavender plumage colour in Japanese quail is associated with a complex mutation in the region of MLPH that is related to differences in growth, feed consumption and body temperature. BMC Genomics, 13:442

Bostein D., White R.L., Skolnick M., Davis R.W. 1980. Construction of a genetic linkage map in man using restriction fragment length polymorphisms. Am. J. Hum. Genet. 32: 314.

Caron N.F., Minvielle M., Desmarais, Poste L.M. 1990. Mass Selection for
45- Day Body Weight in Japanese Quail: Selection Response, Carcass Composition, Cooking Properties, and Sensory Characteristics. Poult. Sci., 69:1037-1045.

Chang G.B., Chang H., Liu X.P., Zhao W.M., Ji D.J., Mao Y.J., Song G.M., Shi X.K. 2007. Genetic Diversity of Wild Quail in China Ascertained with Microsatellite DNA Markers. AsianAust. J. Anim. Sci. 20:1783-1790

Cheng K.M., Kimura M. 1990. Mutations and major variants in Japanese quail. In: Poultry Breeding and Genetics (Ed. by R.D. Crawford), pp. 333-62. Elsevier, Amsterdam.

Devi K.S., Gupta B.R., Prakash M.G., Qudratullah S., Reddy A.R. 2010. Genetic studies on growth and production traits in two strains of japanese quails. Tamilnadu J.Vet. \& Anim. Sci. 6: 223-230.

Eissa E. A., Farahat G.S., Mahmoud B.Y.F., El-Full E.A. 2014 Productive performance and molecular genetics characterization of brown and white Japanese quail genotypes using RAPD and ISSRs-PCR markers. Egypt. J. Genet. Cytol., 43: 73-98.

Farrag S.A., Tanatarov A.B., Soltan M.E., Ismail M., Zayed O.M. 2011. Microsatellite analysis of genetic diversity in three populations of Japanese quail (Coturnix coturnix japonica) from kazakhstan. J. Anim. Vet. Adv.18: 2376-2383.

Graves S., Piepho H.P., Selzer L., DoraiRaj S. 2015. multcompView: Visualizations of Paired Comparisons. $\mathrm{R}$ package version 0.1-7 http://CRAN.Rproject.org/package $=\mathrm{m}$ ultcompView.

Holsinger K.E, Weir B.S. 2009. Genetics in geographically structured populations: defining, estimating and 
Microsatellite marker-body weight-Plumage-color-association-Quail.

interpreting FST. Nat Rev Genet., 10: 639-650.

Hossein E., Cyrus A., Mohammad A.R. 2011. Genetic variation and bottleneck in japanese quail (Coturnix japonica) strains using twelve microsatellite markers. Afr. J. Biotechnol. 20: 42894295.

Inci H., Sogut B., Sengul T., Sengul A.Y., Taysi M.R. 2015. Comparison of fattening performance, carcass characteristics, and egg quality characteristics of Japanese quails with different feather colors. $R$. Bras. Zootec., 44:390-396

Ishishita S., Takahashi M. , Yamaguchi K. , Kinoshita K. , Nakano M. , Nunome M. , Kitahara S. et al. 2018. Nonsense mutation in PMEL is associated with yellowish plumage colour phenotype in Japanese quail. Sci. rep., 8:16732

Jatoi A.S., Sahota A.W., Akram M., Javed K., Jaspal M.H. et al. 2013. Effect of Different Body Weight Categories on the Productive. The J. Anim. \& Plant Sci., 23:7-13.

Kalinowski S.T., Taper M.L., Marshall T.C. 2007. Revising how the computer program CERVUS accommodates genotyping error increases success in paternity assignment. Mol. Ecol., 16: 1099-1106.

Kayang B.B., Inoue-Murayama M., Hoshi T., Matsuo K., Takahashi H., Minezawa M., Mizutani M., Ito S. 2002. Microsatellite loci in Japanese quail and cross-species amplification in chicken and guinea fowl. Genet. Sel. Evol., 34: 233-53.

Kayang B.B., Inoue-Murayama M., Nomura A., Kimura K., Takahashi H., Mizutani M. \& Ito S. 2000. Fifty microsatellite markers for Japanese quail. J. Hered., 91: 502-5.
Kayang B.B., Vignal A., InoueMurayama M., Miwa M., Monvoisin J.L., Ito S., Minvielle F. 2004. A firstgeneration microsatellite linkage map of the Japanese quail. Anim. Genet., 35:195-200.

Lenth R. V. 2016. Least-Squares Means: The R Package lsmeans. J. Statis. Soft., 69:1-32

Liu Y., Liu Y. 1991. Quail's autosexing strain. Page 100 in: Proceedings of the World Quail Conference. USSR National Branch of the WPSA, Tartu, Estonia.

Ma H., Jiang W., Liu P., Feng N., Ma Q., Ma C., et al. 2014. Identification of transcriptome-derived microsatellite markers and their association with the growth performance of the mud crab (Scylla paramamosain). PLoS ONE 9:e89134.

Mahmoud B.Y. F., Farahat G.S., ElFull E.A. 2014. Genetic and phenotypic correlations of body weight, shank length and someegg production-related traits in two Japanese quail genotypes differing in plumage colour. Egypt. Poult. Sci., 34:133-149.

Meng Q.M., Sun Y.Q., Li D.Q., Qiao A.J. 2007. Genetic diversity analysis of Korean quail using microsatellite DNA markers. Fujian J. Anim.Husb. Vet. Med, 1:1-2.

Minvielle F., Gourichon D., Ito S., Inoue-Murayama M., Riviere S.2007. Effects of the dominant lethal Yellow mutation on reproduction, growth, feed consumption, body temperature, and body composition in Japanese quail. Poult Sci, 86:16461650.

Minvielle F., Gourichon D., Moussu C. 2005. Two new plumage mutations in 
the Japanese quail: «curly» feather and «rusty» plumage. BMC Genetics, 6:14.

Minvielle F., Hirigoyen E., Boulay M. 1999. Associated effects of the roux plumage color mutation on growth, carcass traits, egg production, and reproduction of Japanese quail. Poult. Sci. 78:1479-1488.

Mizutani M. 2003. The Japanese quail. In: the relationship between indigenous animals and humans in APEC region, Chang $\mathrm{H} \mathrm{L}$ and Huang Y C. (Eds). The Chinese Society of Animal Science, Taiwan, pp. 1-186.

Nasr M.A.F., Ali E.M.R., Hussein M.A. 2017. Performance, carcass traits, meat quality and amino acid profile of different Japanese quails' strains. $J$. Food Sci. Technol., 54:4189-4196

Nei M. 1973. The theory and estimation of genetic distance in Genetic structure of populations. Honolulu: University of Hawaii Press. United States. pp. 45-54.

Oke U. K., Herbert U., Nwachukwu E.N. 2004. Association between body weight and some egg production traits in the guinea fowl (Numida meleagris galeata. Pallas). Livestock Res. Rur. Devel., 16: 1-10

Pang Y.Z. 2009. Quail Egg from Sexing Supporting Technology Research and Application. China Agriculture Press, Beijing: 62

Peakall R. and Smouse P.E. 2012. GenAlEx 6.5: genetic analysis in Excel. Population genetic software for teaching and research - an update. Bioinformatics 28: 2537-2539.

Petek M., Ozen Y., Karakas E. 2004. Effects of recessive white plumage color mutation on hatchability and growth of quail hatched from breeders of different ages. Br. Poult. Sci., 45: 769-774.
Takezaki N., Nei M. 1996. Genetic distance and reconstruction of phylogenetic trees from

microsatellite DNA. Genetics, 144: 389399.

Thornberry F.D. 2016. Producing quail for home consumption. Available at: http://urbanrancher.tamu.edu/retiredsi telanimals/15215.pdf.

Yildiz M.A., Kesici, T. 1997. Japon bildircinlarda (Coturnix coturnix japonica) sari ve lekeli beyaz tüy rengini belirleyen genler arasindaki genetik iliskinin incelenmesi. Lalahan Hayvancilik Arastirma Enstitüsü Dergisi 37:84-90.

Yilmaz A., Caglayan T. 2008. Egg weight, shape index, hatching weight and correlations among these traits in Japanese quail (Coturnix coturnix japonica) with different colored plumages. Firat Univ. Vet. J. Health Sci.,22: 05-08.

Yu M.Q., Pang Y.Z., Zhao S.J., Wu S.J., Wang Z.B., Yu Y.X., Zhang X.Y. 2009. Black Feather wood pigeon with quail egg mutant sex-linked genetic mechanisms and its plumage study the relationship between gene interactions. Fifteenth National Animal Genetic Breeding with Symposium Proceedings. China Yangling, 438 
الملخص العربى

\title{
تقييم الأداء الإنتاجي في نوعين من لون الريش في السمان الياباني باستخدام

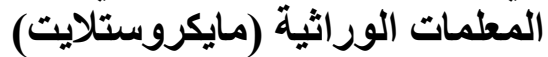

\author{
طارق ربيع \\ قسم الإتتاج الحيو اني - كلية الزر اعة - جامعة قناة السويس- 41522 جمهورية مصر العربية
}

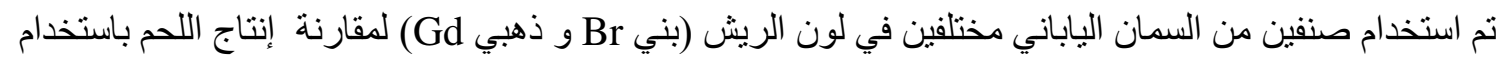

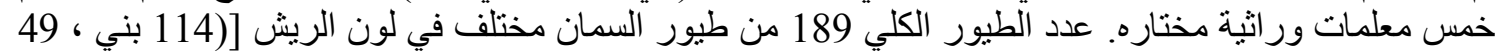

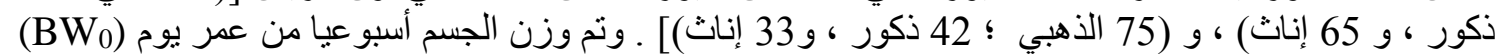

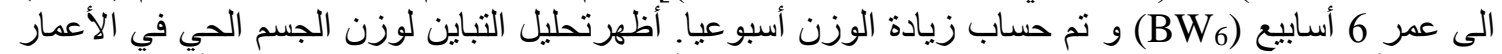

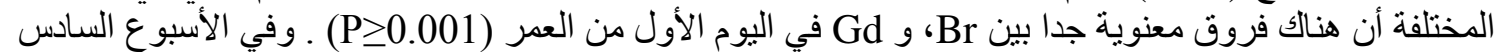

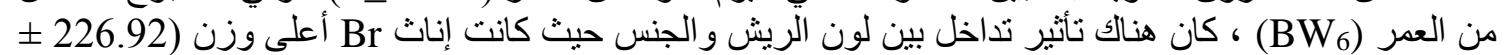

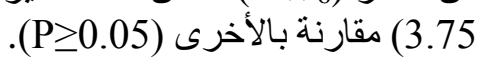

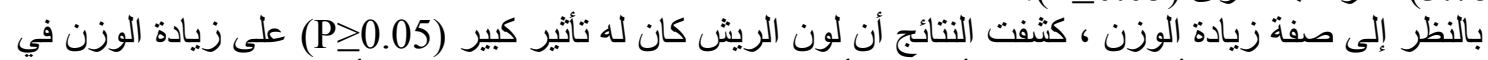

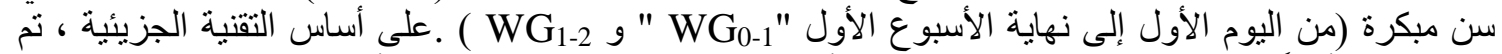

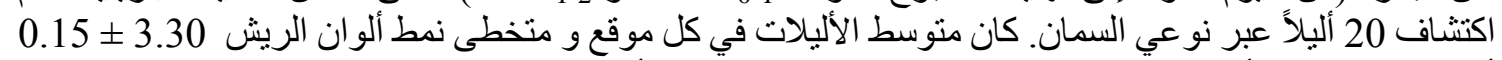

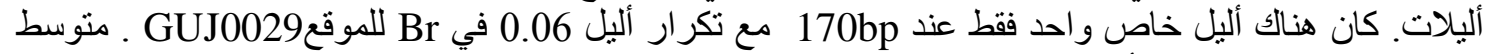

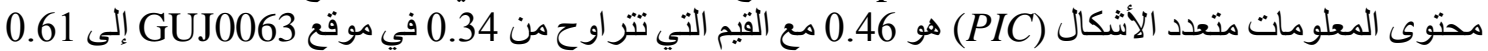

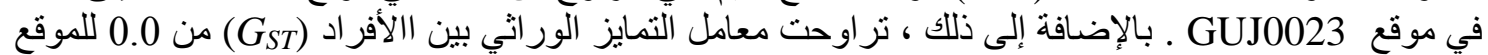

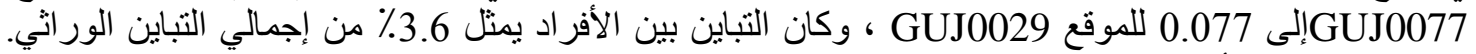

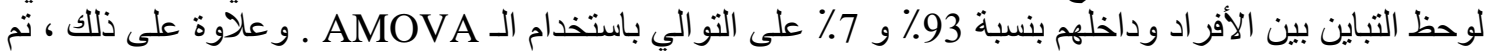

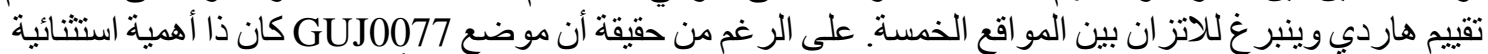

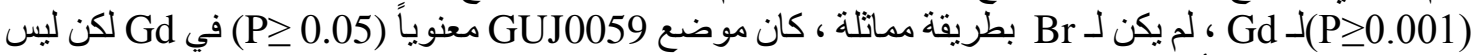

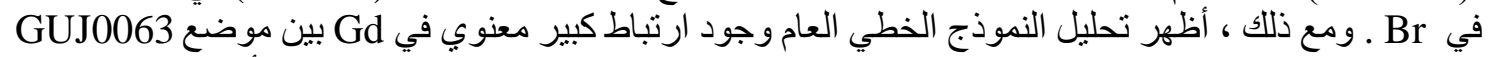

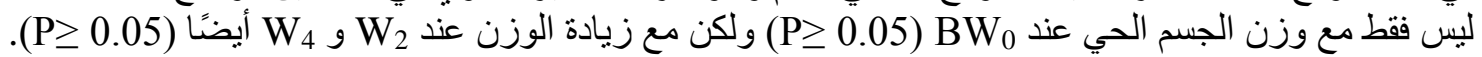

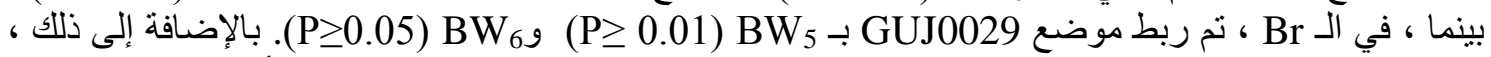

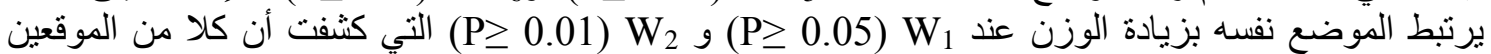
GUJ0029 ، و GUJ0063 مرنبطان بالجينات المسؤولة عن تنظيم وزن الجسم الحي للسمان. في الختام ، تؤكد

نتائج هذه الدر اسة أن العلاقة بين لون الريش و السمات الإنتاجية قد تأكدت و اكتشفت باستخدام الو اسمات الجزيئية. 